\title{
Unsettling Neoliberal Rationalities : Engaged Ethnography and the Meanings of Responsibility in the Dominican Republic and Mexico
}

\section{Sletto, Bjørn}

2016-01

Sletto , B \& Nygren , A 2016 , ' Unsettling Neoliberal Rationalities : Engaged Ethnography and the Meanings of Responsibility in the Dominican Republic and Mexico ' , International Journal of Urban and Regional Research , vol. 39 , no. 5 , pp. 965-983 . https://doi.org/10.1111/1468-2427.12315

http://hdl.handle.net/10138/231391

https://doi.org/10.1111/1468-2427.12315

acceptedVersion

Downloaded from Helda, University of Helsinki institutional repository.

This is an electronic reprint of the original article.

This reprint may differ from the original in pagination and typographic detail.

Please cite the original version. 
Keywords: responsibilization, neoliberal governance, knowledge production, Mexico, Dominican Republic, Latin America, environmental governance, informal settlements, Villahermosa, Santo Domingo

\title{
$<$ INSERT FIRST PAGE HEADER AND COPYRIGHT LINE> \\ $<O N$ SUBSEQUENT PAGES INSERT RUNNING HEADLINE: L.H. = SLETTO AND \\ NYGREN; R.H. = UNSETTLING NEOLIBERAL RATIONALITIES IN THE DOMINICAN REPUBLIC AND MEXICO>
}

\section{$<$ ATL>UNSETTLING NEOLIBERAL RATIONALITIES: Engaged Ethnography and the Meanings of Responsibility in the Dominican Republic and Mexico </ATL>}

\author{
$<$ AU >Bjørn Sletto and Anja Nygren </AU> \\ bjorn@utexas.edu \\ anja.nygren@helsinki.fi
}

\section{$<$ H1 $>$ Abstract $</$ H1 $>$}

$<$ ABSTRACT $>$ Neoliberal urban environmental governance is premised in part on the development of collaborative arrangements between state and non-state actors through which residents in informal settlements are encouraged to participate in their own governance. The neoliberal rationality of participation is implemented through governmental techniques such as responsibilization, whereby residents are rendered responsible for provision of basic environmental services previously seen as the responsibility of government authorities. However, neoliberal urban governance is incomplete, fragmented and fractured, affording room for maneuvering and innovative social agency whereby residents mimic, reinterpret, negotiate, and contest neoliberal subject formations. In this article, we discuss how engaged scholarship can facilitate such alternative productions of neoliberal subjectivities through the development of 'knowledge encounters'. We draw on cases of solid waste management and environmental risk governance in the informal settlements of Los Platanitos, Santo Domingo Norte, Dominican Republic, and Gaviotas Sur, Villahermosa, Mexico, to suggest that knowledge encounters facilitated through engaged ethnography furnish stages for alternative conceptions of responsibility, whereby residents negotiate neoliberal techniques of governance through diverse forms of acquiescence, reconfiguration and contestation. </ABSTRACT >

\section{$<\mathbf{H} 1>$ Introduction $</ \mathrm{H} 1>$}

Urban environmental governance in the Dominican Republic and Mexico has devolved from the sole purview of government authorities to partnerships between civil society, privatesector and government actors, reflecting the various forms of horizontal approaches to urban governance characteristic of neoliberal rationality. In the case of the Dominican Republic and Mexico, these partnership arrangements are evident in the privatization of environmental risk management and waste collection services. The reimagining of these services from a governmental responsibility to a problem of governance has been shaped by a powerful rationality of civic participation in urban governance. This rationality of participation serves to depoliticize the structural causes of environmental risks and failures in waste provisions and thus legitimizes the logic of neoliberal governance. At the same time, the rationality of participation resonates deeply with traditions of collaborative community development and civic engagement in the Dominican Republic and Mexico, thus fostering common-sensical consent among residents in marginalized communities to participate in their own governance.

The particular form of participatory rationality in the Dominican Republic and 
Mexico is mobilized through a variety of techniques of governance, including subtle forms of persuasion aimed at involving residents of informal settlements, their community organizations and other civil-society actors in horizontal forms of participatory urban planning. A particularly important persuasive trope is the discursive construction of 'responsibility', which we understand here as an indirect technique of 'responsibilization' (Shamir, 2008). This trope of responsibility is deployed as a premise for neoliberal citizenship (Lacey and Ilcan, 2006; Raco, 2007) and thus serves to reproduce the commonsensical logic of participation in environmental risk and waste management. However, considering the specific social context of Dominican and Mexican neoliberal governance, it is necessary to complicate the assumption of inevitability and hegemony of such techniques of governance. In our view, subject formation through neoliberal governance is 'neither a smooth nor a complete project' (Li, 2007: 1-3; Mckee, 2009: 474). Self-responsibilization of the neoliberal subject is complicated by residents of informal settlements who resist, contest, appropriate and deflect the participatory rationality of neoliberal governance. In the case of the Dominican Republic and Mexico, as residents of informal settlements engage in the participatory structures of neoliberal governance, they conceptualize alternative meanings of civic responsibility through subversive forms of speaking, quiet encroachments, strategic alliance building, and everyday resistance, contestation and other 'insurgent forms of the social' (Bayat and Biekart, 2009; Holston, 2011).

Ironically, the production of such alternative meanings of civic responsibility in the Dominican Republic and Mexico is encouraged by the same structures of neoliberal governance that aim to produce the neoliberal subject (Gunder and Hillier, 2007) - that is to say, as neoliberal governance devolves into horizontal assemblages of urban planning actors, spaces of engagement are created to structure civic involvement of residents of informal settlements and their organizations. However, because of the specific traditions of community and collaboration in the Dominican Republic and Mexico, these spaces also furnish opportunities for critical knowledge encounters, namely forms of engagements shaped not merely by neoliberal governance but also by past experiences of civic engagement that facilitate critical thought and reflective learning among and between marginalized residents and planning actors, thus furthering the co-production of alternative knowledges and conceptualizations of rights and responsibilities.

In the discussion that follows we examine the complex and unpredictable role of engaged ethnography in facilitating such critical knowledge encounters and thus furthering critical re-imaginings of the meanings of responsibility under participatory neoliberal governance. Here we understand engaged ethnography as a complex arena for critical thinking and co-production of knowledge that has the potential to generate new ways of reasoning and new forms of acting (Biehl, 2013). While we build on situated ethnographic analysis to further our understanding of contestation under neoliberal governance (Mckee, 2009; Trnka and Trundle, 2014), we deem it important to consider the ethnographer's position within the fields of power that structure subject formations and shape the possibilities of alternative knowledge production (Clarke, 2010; Osterweil, 2013; Lee, 2014). $<$ F1 $>$ As our privileged position is appropriated by residents to argue for their interests, through our uneasy interlocutions we also (unwittingly) reinterpret or complicate residents' meaning making and become active co-producers of neoliberal subjectivities through our fraught collaboration with government authorities. Thus, co-production of knowledge facilitated by ethnographic engagement is implicated in multifaceted negotiations over self, community and civic responsibility under neoliberal governance. Just as the co-production of knowledge is dynamic and always incomplete, conceptualizations of responsibility are always in the making as residents acquiesce to, reconfigure and contest dominant constructions of responsibility in ongoing processes of subject making. 
We base our discussion on our work in the informal settlements of Los Platanitos in Santo Domingo, Dominican Republic, and Gaviotas Sur in the city of Villahermosa, Mexico. Both of these marginal communities suffer from environmental hazards and inadequate solidwaste management under conditions of neoliberal governance and are subject to indirect acts of governing through governmental techniques of responsibilization. In both cases, traditions of community collaboration in addressing collective problems surrounding urban infrastructure have facilitated the particular rationality of participatory governance while, at the same time, have provided a resource for critical reflection and oppositional construction of responsibility in the very spaces of engagement produced under neoliberal governance.

Los Platanitos was developed through self-build strategies at the site of a large landfill in the 1980s, as residents in a collaborative effort brought in rocks and other infill and erected small homes with found materials such as empty oil barrels, used plywood, and zinc sheeting. The community still has no formal infrastructure services, unemployment and poverty rates remain high, and education levels are very low. At the same time, residents have developed communal support structures in the form of informal economic networks, governance structures and social support mechanisms (Bossin, 2009; Pusch, 2010; Strange, 2010; Díaz, 2011). Sletto has worked with residents of Los Platanitos and Dominican civil society organizations since 2008, in most cases accompanied by graduate students attending his service-learning courses that focus on environmental risk and solid-waste management. He works closely with his students and collaborating researchers from Dominican organizations, conducting interviews, facilitating and observing focus-group discussions and interactive workshops with residents, and moderating meetings with civil society organizations and government representatives, continuously inhabiting an uneasy position as activist, interlocutor, researcher and educator.

In Villahermosa, rapid population increase in the 1980s spurred by the growth of the oil industry led to the development of the informal settlement of Gaviotas Sur on low-lying land near the city center, which is exposed to devastating floods. The residents built precarious homes using diverse forms of self-help and collective efforts, and, in the absence of public services, they developed informal, collaborative strategies to cope with deficiencies in basic infrastructure provision. Many households in Gaviotas Sur still do not have access to clean water and must contend with poor and limited sanitation, waste collection, health care, and security services. Nygren has conducted interviews, group discussions and social mapping of flood risks and vulnerabilities with local residents in Gaviotas Sur since 2008, focusing on resident strategies to cope with flood risks and manage everyday vulnerabilities. At the same time, she has also organized workshops and training sessions for federal, stateand city-level government officials, private consultants and NGO representatives to discuss environmental risks and mitigation strategies. This work has put her in a contradictory but unique position to document residents' efforts to contest neoliberal governance schemes in Villahermosa and to reconceptualize responsibility for infrastructure services.

As we will demonstrate in the following pages, the focus-group discussions, workshops and training sessions in Los Platanitos and Gaviotas Sur have indeed been framed and shaped by the structures of engagement under neoliberal governance in Santo Domingo and Villahermosa. However, they can also be understood as critical knowledge encounters that have served to further residents' reconceptualization of dominant constructions of responsibility in surprising and contradictory ways. In order to further our discussion of the complex role of engaged ethnography in developing such critical knowledge encounters, we draw on the literature in feminist epistemologies to argue for a more complex understanding of knowledge production and subject formation under neoliberal governance. We focus on the role of engagement in engaged ethnography, namely the ways in which knowledge is coproduced through knowledge encounters between community members, authorities, civil- 
society actors and scholars such as us, ultimately leading to articulations of alternative understandings of rights and responsibilities.

We then turn to a discussion of our own ethnographic engagements in Los Platanitos and Gaviotas Sur. We draw on interviews, focus group discussions, and participant observations to illustrate how dominant constructions of responsibility associated with environmental risk management have alternatively been met with acquiescence or been reconfigured or contested by residents in both communities. Furthermore, we critically examine our own roles in the development of these knowledge encounters and in the coproduction of knowledge that informed these alternative articulations of responsibility. Based on our critical perspective on knowledge as situated, contingent and co-produced, we conclude with reflections on the complex and contradictory roles of engaged ethnography in the context of participatory yet subjectifying structures of neoliberal governance.

\section{$<$ H1 $>$ Neoliberal governance, responsibilization and engaged ethnography $</ \mathrm{H} 1>$}

Under neoliberal governance, centrist governance structures in Latin America and elsewhere in the global South have yielded to hybrid governance regimes that operate through dynamic networks between multiple actors and institutions in governmental, private and civil-society sectors (Caldeira, 2008; Guarneros-Meza, 2009). In these polycentric arrangements, state-led forms of regulation are combined with market-driven standardizations, public-private partnerships and voluntary agreements (Gandy, 2006; 2008; Fraser, 2009; Bogaert, 2011). By encouraging individual actors and collectives to participate actively in urban infrastructure management and service provision, the prevailing forms of co-governance provide more space for action to individuals and community groups but, at the same time, such individualization of responsibility places more blame on civil society actors in the case of failure (Lemke, 2001: 202). Such outsourcing allows state agents to legitimize interventions that would otherwise meet with considerable resistance (Bayat and Biekart, 2009), in part because civil-society actors find it difficult to contest actions or make claims in the absence of clear channels of representation and accountability (Swyngedouw, 2005: 2002). In the case of the Dominican Republic and Mexico, by shifting service provisions and environmental regulation to private companies and civil-society and community-based organizations, new, quasi-public institutions have been invented to serve as mediators between the state and residents. These institutions are often more intimately integrated into the neoliberal forms of governance than traditional NGOs, thus furthering the hegemonic drive of neoliberalism to 'stabilize state-citizen relations by implicating civil society in governance' (Miraftab, 2009: $32)$.

Thus while neoliberal governance enables new forms of articulation between social actors, such polycentric strategies also restructure relations of power in political decision making and implementation, creating new dependencies through the very rationale of 'enabling' empowerment through participation (Trnka and Trundle, 2014). Viewed from the Foucauldian perspective of governmentality (Elden, 2007), indirect state control through networked governance is made possible through discourses that rationalize the effectiveness of such decentered forms of environmental governance, coupled with interventionist practices and techniques of power whereby the rationalities of discourse are implemented (Lemke, 2001; see also Rose et al. 2006). Thus, while participation in environmental governance is constructed as common-sense 'knowledge' about the potential of participatory governance to improve people's lives and reduce risks and vulnerabilities, governmental techniques of civilsociety involvement in urban planning and policy making are designed to enforce the rationality of participation (Dawson, 2004; Swyngedouw, 2005; Bayat and Biekart, 2009). Through 'structures of inclusion' characteristic of neoliberal governance (Miraftab, 2009: 32), participation becomes delinked from any projects of emancipation and instead 
conceived of as a 'loose toolkit' for 'good governance' (Baiocchi and Ganuza, 2014: 31), which provides the rules for appropriate forms of participation by subjects that are discursively constituted as 'governable' (Mckee, 2009).

Central to the constitution of the governable subject under neoliberal governance is the technique of responsibilization, that is, the mechanisms by which subjects are rendered responsible for tasks previously seen as the responsibility of government authorities (Clarke, 2005). The technique of responsibilization works through discourse but also through interventionist practices, such as the structuring of civic participation in ways that facilitate the inclusion of docile, responsible subjects while excluding unruly and hence irresponsible subjects (Comack and Bowness, 2010: 43). Since these structures of civic involvement constitute the meaning of responsibility largely in neoliberal terms (Gabay, 2011; Trnka and Trundle, 2014: 137), responsible subjects are considered those who are entrepreneurial, autonomous, make 'reasonable' choices (Clarke, 2005: 451), and are thus empowered to assume responsibility for their self-governance.

While the neoliberal rationality of governance 'engages in the production of various modes of subjectification' (Lacey and Ilcan, 2006: 36), the governmental technique of responsibilization is also reinforced by practices of self-surveillance and self-assessment (Shore and Wright, 2011) that reflect the ways in which power operates on the body itself under neoliberal governmentality (Foucault, 2003). In terms of environmental risk management, as residents in informal settlements are drawn into networked forms of governance through the bio-political construction (Foucault, 2007) of 'resilient' subjects (Coaffee, 2013), they participate actively in the self-regulation of their individual conduct (Rose, 2000: 324).

However, rationalities of governance through structures of participation 'are not fixed or universal, but heterogeneous and historically contingent' (Mckee, 2009: 468). The techniques of responsibilization are contingent not only on social but also on material relations within specific spaces. Thus, governing is 'characterized by contradictions, complexities and inconsistencies, a gulf between policy rhetoric, implementation and practices and the fact that outcomes are often partial, uneven and unpredictable' (Flint, 2002: 621), which means that subjection is also inherently incomplete (Mckee, 2009: 475). Furthermore, the incompleteness of subjection cannot merely be attributed to fractures in governance regimes: it is also the result of the tactics and representations of those subjected to techniques of neoliberal governance.

In order to consider the counterhegemonic potentials of such oppositional practices among marginalized populations in the Dominican Republic and Mexico, we focus here on what Trnka and Trundle (2014) call the 'staging of enactments' in the face of the technique of responsibilization. We propose that such enactments should be understood as socially and spatially contingent negotiations in the face of neoliberal governance; that is, they reveal not merely the self-regulation of responsibilized neoliberal subjects but also the reflexivity and hence agency of subjects. As Centner (2012) has suggested in the case of Buenos Aires, it is necessary to rethink the forms of social citizenship under neoliberalism by focusing on the strategic claim makings on the part of heterogeneous social groups. Through 'their strategic yet flexible attachment to material space in the city' (Centner, 2012: 338) and their tactical engagement with everyday politics, different groups adopt and yet reconfigure the neoliberal rationalities of urban governance for their own purposes. In the case of the Dominican Republic and Mexico, we suggest that the spaces of engagement facilitated by the agents of neoliberal governance - civil society representatives and government officials-furnish stages for unpredictable enactments of self and community, thus facilitating marginalized residents' conceptualizations of alternative meanings of responsibility as they confront dominant 
projects of responsibilization through heterogeneous and strategic claims based on material and social specificities.

However, to illuminate the emancipatory potentials of such alternative conceptualizations of responsibility, it is necessary to understand the governmental technique of responsibilization not merely as an expression of power but also as an incomplete and constantly evolving project of hegemonic knowledge production. In places such as Los Platanitos and Gaviotas Sur, the neoliberal project of participatory governance seeks to constitute the governable subject by subjugating alternative forms of action but also alternative forms of thought (Simone, 2008). In order to locate the emancipatory potential of such staging of enactments in the face of hegemonic constructions of responsibility it is, therefore, necessary to conceptualize knowledge as co-produced in socially contingent 'knowledge encounters' between residents and a diversity of government and civil-society actors, including engaged ethnographers such as us (see also Asher, 2005; Bartlett, 2005, Elwood, 2009). This means we challenge the dualistic categories of local and scientific knowledge (Haraway, 1991; Agrawal, 1995; Nygren, 1999), instead suggesting that northern scholars working in places like Santo Domingo and Villahermosa are intimately involved in both challenging and reproducing hegemonic structures of knowledge, including neoliberal constructions of the responsible subject (Alexander and Mohanty, 2010; Mohanty, 2003; Peake and de Souza, 2010). From such a perspective, the alternative conceptualizations of responsibility emerging from informal settlements such as Los Platanitos and Gaviotas Sur can be understood as co-produced knowledge formations, emerging through enactments and tactics that are both self-regulatory and oppositional.

However, since such enactments are situated within the dominant rationalities and structures of neoliberal governance, it is critical to consider how spaces of engagement can be developed in practice in order to facilitate emancipatory knowledge encounters. As Osterweil (2013: 598-99) notes, the concept of 'engaged scholarship' is widening to include a multiplicity of engagements ranging from direct activism to critical deconstruction of hegemonic categories. From this perspective, critical thought and analytical reflection should not merely be considered as 'oppositional' but as crucial elements of 'engaged action' (Mullins, 2011). In cases where engaged ethnographers work with residents who are living in conditions of extreme marginalization and who are differently situated within hierarchies of class, political power, gender and ethnicity (Ghose 2007; see also Elwood, 2006: 199; Brown and Knopp, 2008: 44), a reflexive approach to collaborative process may spark practices of knowledge production that have decolonizing potentials and can lead to deliberative social change (Roy, 2005; Blomley, 2008; Peake and de Souza, 2010: 119; Roy, 2011). By foregrounding co-productive understanding and conceptualization of critical issues such as environmental risk management, engaged ethnography has the potential of challenging deterministic claims of knowledge and power, and facilitating diverse, although often ambiguous, forms of 'joint learning' (Walsh, 2005, Cerwonka and Malkki, 2007: 14; Biehl, 2013). Thus, through the production of critical knowledge encounters, new conceptual frames can be created to challenge categorical ways of thinking (Shapiro, 2013: 30) associated with techniques of neoliberal governance.

\section{$<$ H1 $>$ Solid waste management, responsibilization and knowledge encounters in Santo Domingo, Dominican Republic $</ \mathrm{H} 1>$}

Santo Domingo is considered a prime model of 'municipal neoliberalism' in Latin America (Goldfrank and Schrank, 2009), where participation is rationalized as a fundamental premise for effective environmental governance and implemented through practices such as mesas de concertación (roundtables), talleres (workshops) and processes of participatory budgeting, during which residents, civil-society groups and government actors engage to draft action 
plans and development strategies. Through the structuring of such spaces of engagement in accordance with neoliberal rationalities of networked governance, participatory governance strategies serve to naturalize the 'progressive neo-liberalization' in the Dominican Republic (Bosman and Amen, 2006: 228; see also Mitchell, 2008), producing residents of informal settlements as incomplete subjects whose right to a voice in decision making is contingent on their learning appropriate modes of participation.

The discourse of participatory governance is reproduced through legal, policy and planning documents via language that couples effective governance with forms of participation predicated on individual and community responsibility. In the Ley Orgánica de la Estrategia Nacional de Desarrollo de la República Dominicana 2010-2030 (Organic Law of National Development Strategy for the Dominican Republic 2010-2030), Article 7 calls for 'a state of social and democratic rights, with institutions that act ethically, transparently and efficiently in the service of a society that is responsible and participatory' (Senado de la República Dominicana, 2012: 7). Similarly, the Plan Estratégico de Desarrollo de la Educación Dominicana 2003-2012 (National Development Strategy for Education in the Dominican Republic 2003-2012) is published under the slogan 'Constructing a future of solidarity: the will of the nation' and it calls for forms of education that 'provide people with human development competencies such as communication, cooperation and responsibility' (Secretaría de Estado de Educación, 2003: 34).

At the municipal scale in Santo Domingo, responsibilization is similarly effected through a discourse of participatory governance, but with more immediate implications for environmental management practice. An individualized construction of responsibility is reflected in such programmatic statements as the 'Municipal waste management regulations', Article 15 of which addresses the significance of shared assumption of responsibility to achieve proper waste management: 'Shared responsibility among producers, importers, exporters, businesses, consumers and executive powers as well as municipal authorities is fundamental to achieve a form of integrated management of solid waste that is environmentally effective, technologically viable and economically feasible' (Ayuntamiento del Distrito Nacional, 2011: 15).

Here the concept of integrated solid-waste management serves to link the discourse of responsibility with the horizontalizing, depoliticizing practice of neoliberal governance. A particular example of this coupling of neoliberal rationalities with neoliberal governance practices is the contract services for garbage collection in the informal settlements lining the Ozama and Isabela rivers in Santo Domingo Distrito Nacional. After solid-waste management was privatized in Santo Domingo in the early 1990s, private companies failed to provide garbage-collection services to these informal settlements because of safety concerns and inadequate road networks. This led to massive protests. As a solution, the city authorities contracted five community-based organizations to provide waste collection, while requiring all NGO revenues be spent on infrastructure repairs and environmental education within the community. Through this commodification of municipal solid waste, community-based organizations in Santo Domingo assumed control over environmental management in their neighborhoods, which, in turn, has led to significantly improved garbage collection and a regular supply of funds for infrastructure improvements and employment. This arrangement has also strengthened the administrative capacities of these organizations, providing them with greater legitimacy and access to international donors.

At the same time, these NGOs have relieved city agencies of the responsibility to perform these public services (Chantada, 2014). Now it is these organizations instead of municipal agencies which, through public education and community outreach efforts, exhort residents to take responsibility for keeping public spaces clean of household waste, and it is these organizations that receive residents' complaints in cases of failure in waste collection. 
However, although their uneasy position as intermediaries between the municipal government and residents has made these organizations agents of responsibilization, members of the organizations also see their contract relationship with the municipal administration as an opportunity to exert pressure on local government to address community needs. Their contractual relationship with the municipality notwithstanding, they still view themselves as community activists serving oppositional and even radical roles. Thus, the enactments of responsibility on part of these organizations are complex, inconsistent and constantly evolving, as they negotiate their positionality vis-à-vis the participatory rationality of neoliberal governance: they are not merely uncritical governmental agents engaged in the production of neoliberal subjects, nor are they exclusively engaged in the production of oppositional subjects.

Since 2010, these organizations have played an important role in prompting critical reconceptualizations of hegemonic constructions of responsibility in Los Platanitos. One of the principal aims of our work in Los Platanitos has been to challenge the 'invited spaces' of engagement (Miraftab, 2009: 35) established by municipal authorities in order to facilitate supportive relationships between residents and civil-society organizations, strengthen organizing capacities, and ensuring continuity of community development initiatives in Los Platanitos. We have drawn on this network of civil-society actors to facilitate meetings, workshops and other forums for critical deliberation, with the goal of sparking knowledge encounters that can bring forth alternative conceptualizations of shared futures.

In particular, our work in Los Platanitos has focused on the severe environmental and public health problems associated with inadequate solid-waste management. No municipal waste collection is provided in this densely built community and, in its absence, residents have devised a variety of strategies to remove trash: by depositing it in empty lots, public spaces and the creeks bisecting the community; by organizing communal operativos (volunteer actions) to remove trash from public spaces; by burning the trash or carrying it up steep and crumbling staircases to deposit it at informal collection points in adjacent neighborhoods served by private solid-waste collection firms. Thus, in Los Platanitos, household waste is ever-present-littering the narrow alleyways, piled behind people's homes and floating lazily down the creeks, where it accumulates in narrow spots and in front of culverts, blocking water flow and exacerbating the flooding that routinely follows heavy rains.

Because of the severity of the trash problem in Los Platanitos, in 2010 Sletto, in partnership with community leaders and civil-society partners COPADEBA and Centro Montalvo, developed a service learning project to document residents' solid-waste management practices and the social and environmental problems caused by trash accumulations. Since students and community researchers were already examining the solid waste issue, the service learning project provided an opportune space for facilitating a knowledge encounter between residents and the community-based solid waste management organizations operating in Santo Domingo Distrito Nacional. Through such a knowledge encounter, representatives of these organizations could inspire new thinking about the trash problem in Los Platanitos, including critical reflection over causes, consequences and responsibility for solid-waste management in the community. After conferring with project partners and community leaders, in January 2010 Sletto invited representatives of six community-based solid-waste management organizations to visit Los Platanitos and speak about the history of their organizations, the challenges they had faced and the strategies they had chosen to overcome these obstacles.

When the six speakers arrived in Los Platanitos, community leaders directed them to a small patio in front of the local representative of project partner COPADEBA, where they were soon joined by approximately fifty community members. In their presentations, the 
speakers enacted their uneasy position as activists-cum-government-actors, seeking to inspire community action but at the same time replicating the participatory rationalities of neoliberal governance. While exhorting residents to assume responsibility for the solid-waste problem in their community instead of relying on the government, they also sought to underscore the agency of residents to act in the face of governmental authority. In addition to the didactic language of self-responsibilization they drew on heroic tropes of Dominican storytelling, with each speaker relating their experience of living in a community that once suffered from the same problems as Los Platanitos, but which had now been dramatically improved through collective action. As Guillermo, the leader of one of these organizations said during his presentation, 'What you can do here [in your community] doesn't depend on those who come from the outside, it depends on what is here inside'. $\langle\mathrm{F} 2\rangle$ Jaime, another representative of one of these organizations, continued, 'What I solve for my community, that benefits me because I live in that community'.

This event sparked much enthusiasm but also unexpected contestation, critical thinking and reconceptualization of the very meaning of responsibility among residents in Los Platanitos. For some residents, the concept of converting trash from a problem to a potential source of income was a profound inspiration. Following the presentation, a group of older male community leaders decided to form a new community-based organization, Fundación Los Platanitos (FUMPLA). The organization is still active and represents an important step in terms of community organizing. However, the establishment of this organization has had its own challenges. By modeling their fledgling community organization on the established solid-waste management organizations, the founders of FUMPLA embraced the premise of the commodification of environmental services. In the words of one of the group leaders in 2010, 'If we had a reliable service where our trash could be picked up, we ourselves would take care of our garbage. Now weeks can go by and the trash accumulates, but if there was a collection service with salaried workers, that would be a success. [With some money] this problem would be solved right away'.

In foregrounding the income-generating potentials of community-based waste conversion, FUMPLA leaders have tended to replicate the neoliberal discourse of responsibility, suggesting that residents in Los Platanitos lack critical awareness of the solidwaste problem. The statement of one of the leaders made during a focus-group discussion in 2010 reflects a sentiment he frequently repeated in informal conversations with Sletto: 'In this community, people should be more conscientious and realize that the garbage they throw in the creek affect all of us'.

This acquiescence to hegemonic constructions of responsibility on the part of community leaders, coupled with their appropriation of neoliberal concepts of commodification of environmental services, illustrates the unexpected and sometimes disturbing implications of engaged ethnography. While these community leaders raised expectations among residents that they could quickly secure a contract for solid-waste removal, the municipality of Santo Domingo Norte is still merely exploring options for entering into a service arrangement with FUMPLA. Thus, by speaking of trash removal as an economic opportunity for community members rather than as the responsibility of government, leaders of FUMPLA are subtly altering the conceptualization of solid waste management and lessening the intensity and frequency of residents' claims for garbage removal leveled against the municipal authorities. We are therefore left with a paradox: while ethnographic engagement gave residents the impetus to form their first organization, increased the potential for capacity building and provided new opportunities to take advantage of the spaces of engagement provided by neoliberal governance, some of its leaders have emerged as agents of responsibilization.

However, this knowledge encounter also led to contestations of neoliberal 
constructions of responsibility. In focus group discussions and workshops following the visit by the community-based solid-waste management organizations, residents began to engage in critical conversations about the underlying causes of the trash problem and the role of the individual or the community versus the government in addressing this issue. In particular, these encounters have provided a space for critical assessments of the origin of trash in the creek that bisects the community: many residents now point out that those who are responsible for creating the trash problem are spatially and socially situated in what they call the 'above' (arriba) - the higher-income neighborhoods located in the surrounding hills above, and, within Los Platanitos, upstream from the most marginalized households. As one resident noted in a focus-group discussion in 2010, 'One needs to be conscious of the fact that the garbage will flow [downstream], and that hurts those who live below'. Similarly, Manuel, who lives adjacent to the creek in the most precarious downstream area, stated: 'The filth in this creek stems directly from the throwing of trash, they throw too much trash, all the households above throw their trash into the creek'.

At the same time, other residents contest the individualization of responsibility that is so often replicated by the leaders of FUMPLA. Instead, they suggest, by fostering a stronger sense of community residents can take collective action to address these challenges. They thus deflect the neoliberal construction of responsibility into a narrative of community-based consciousness. As Reyna, one of the female-group leaders, suggested in a focus-group meeting in 2010, 'We need to deal with the trash problem ourselves; to me it's about all of us uniting and working together here in our barrio, everyone uniting to form an organization to deal with this problem'.

These contestations of individualized constructions of responsibility are prompted in part by skepticism or even outright rejection of FUMPLA's premise of partnership with government for trash removal in return for employment and infrastructure improvement. Thus, the very acquiescence to the neoliberal discourse of individual responsibility on the part of FUMPLA leaders, problematically facilitated by ethnographic engagement, has prompted the sort of critique of the role of the state which, according to residents, is rarely witnessed in Los Platanitos. As Roger noted as he was criticizing the municipal authorities for abdicating their responsibility:

$<$ EXTRACT > The political parties only sometimes remember our poor and modest sector, because there are many votes here. And then when they have achieved their objective, they forget our poor and abandoned community. We are also people who deserve to live in dignity, like others live ... We need to get the authorities to see [how we live] so they don't forget this ... Because we are citizens and ... we have nowhere else to raise our children (Roger, participant in focus-group discussion, 2010). </EXTRACT>

However, these contestations of hegemonic constructions of responsibility should not simply be read as evidence of growing 'resistance' to state hegemony. Instead, these contestations may be thought of as innovative reconfigurations of subjectivities in the context of masculinist structures of community authority. In the case of Los Platanitos, the top leadership of FUMPLA is exclusively male and the organization is dominated by paternalist community leaders. The organization has tended to replicate conventional gender relations in Los Platanitos, its leaders reproducing a strongly gendered discourse of responsibility. Organized community action oriented towards government is seen as the purview of men, while women's responsibility and authority is considered to remain in the domestic sphere.

Because of the masculinist character of community participation structures, our ethnographic engagement in Los Platanitos has striven to create supportive spaces where 
women's voices can be heard, in part by drawing on the dominant rationality of participation 'by all' that undergirds Dominican neoliberal governance. In so doing, we have attempted to include women in the critical co-production of knowledge regarding alternative solid-waste management. In focus-group discussions, workshops and other knowledge encounters, women have engaged in deliberations about waste management which have, in turn, brought forth alternative conceptualizations of rights and responsibilities that challenge situated hierarchies at multiple levels. They have appropriated the male domain of problem solving and organizing to address the solid-waste problem, and thus engaged in the co-production of situated knowledge of alternative, community-based development interventions.

A prominent example of the new spaces of engagement opened for women is the vermicomposting $<\mathrm{F} 3>$ project started by the community-based women's group Mujeres Unidas in January 2012 with technical and funding assistance from our research initiative. In January 2014, an outcome assessment of the pilot phase of the project was conducted by Mujeres Unidas together with Sletto, graduate students, and members of Centro de Investigación y Acompañamiento a Mujeres y la Familia (CIAMF). Despite the challenges the women had faced during the pilot project, including flooding and invasion by rats and other pests, they decided to rebuild the composting site and implement the second phase of the project. They saw the potential of vermicomposting in mitigating the organic waste problem, but they also viewed their organization as a space for cultivating a new role for women in community development within a highly gendered landscape. Thus, the knowledge encounters we facilitated between members of Mujeres Unidas, civil-society actors and government agents have prompted enactments that challenge gendered constructions of responsibility for action.

This means that the discourse of Mujeres Unidas represents in part acquiescence to the governmental technique of responsibilization by placing the imperative for action within the community. However, Mujeres Unidas is also challenging the claim that the responsibility - and hence the right - to solve problems falls solely within the purview of the male leaders of FUMPLA. Thus, through their reconfiguration of meanings of responsibility commonly deployed in community discourse, the female members of Mujeres Unidas are challenging gendered forms of self-responsibilization. As Tina, a Mujeres Unidas member, said during the vermicomposting outcome assessment in January 2014, this reconceptualization of responsibility has been a contested process: 'People respect us now because when we have our meetings, there are more than sixty women ... working ... it's something really impressive'. And Jasmina clarified: 'If a group of twenty to thirty women show up, you can hear them, but not if I come alone. When we arrive with so many people, they listen to us and we can achieve what we want'. She then added, 'After the project with the worms we get together more ... we look for new options for taking care of the community. We [the women] are prepared for this'.

Ultimately, through our ethnographic engagement in Los Platanitos we have sought to challenge self-responsibilizing norms of participation and existing hierarchies by opening new, critical spaces of engagement for different kinds of residents. Through ethnographic engagement, new speakers and new meanings of responsibility have emerged, reflecting acquiescence but also reconfigurations and contestations of the neoliberal techniques of responsibilization. The implications for critical action are still to be fully understood, in the same way as the actual program for community-based solid waste management has not yet been actualized. However, through the knowledge encounters we have facilitated between residents, city agencies and civil-society organizations, residents increasingly question their paternalistic relations with the city administration while contesting the male prerogative to assume the responsibility for addressing community problems. 


\section{$<$ H1 $>$ Environmental risk management and alternative conceptualizations of responsibility in Villahermosa, Mexico $\langle/ \mathrm{H} 1>$}

In 2007, a catastrophic flood inundated more than half of the city of Villahermosa, Mexico, prompting state and municipal government authorities to pursue new modes of urban governance premised on citizen self-help and individual responsibility. This discourse of civic responsibility is reproduced in state-wide and municipal development plans and risk management strategies. The Plan Estatal del Desarrollo 2007-2012 (State Development Plan 2007-2012) seeks to 'transform [the state of] Tabasco to a participative society, with a government that is inclusive ... and close to people' (GET, 2010: 32). And the Comisión Nacional de Agua (CONAGUA or National Water Commission) aims to 'consolidate the participation of the users and organized society in water management ... by creating conscience among the population of the necessity for payment and responsible and efficient use of water' (CONAGUA, 2011). Through its Culture of Water program, CONAGUA strives to promote a 'positive and proactive change in the individual and social participation in the sustainable use of water', which, according to CONAGUA, requires 'transformation of individual and collective values, beliefs, perceptions, understandings, traditions, abilities, attitudes, and conducts in relation to water and everyday life'. As an official of CONAGUA stated in one of the group discussions:

$<$ EXTRACT $>$ People want us to protect them with embankments and flood walls but this is impossible ... We need good territorial ordering and good programs of adaptation. People are constructing their houses on whichever terrain; there isn't any culture of risk prevention ... It's important to learn to live with water (Official of CONAGUA, participant in a group discussion, 16 February 2011). EXTRACT>

After the 2007 flood, city officials of Villahermosa in partnership with private companies and NGOs embarked on expansive zoning and land-use planning projects in areas at risk of flooding, including the informal settlement of Gaviotas Sur, located in the swampy lowlands along the Río Grijalva. This effort included programs to regulate home construction, projects to displace residents living in high-risk zones, and relocation of informal street vendors to a registered market where 'modern standards' of waste management would prevent waste from blocking drains. Also, street names in Gaviotas Sur were registered and residential plots numbered in order to create 'an urban territory with order and equilibrium', in the language of the Plan Estatal de Desarrollo (GET, 2010: 156).

In keeping with the discourse of civic responsibility, governmental authorities have contracted flood management consultants and NGO facilitators with expertise on participatory methods to advance these land-use and waste-management agendas. The programs are premised on civic participation as a means of furthering citizen awareness, fostering behavioral change and building citizens' capacity to develop their own initiatives for mitigating vulnerability (GET, 2010, PEOT, 2008). While these programs have strengthened local involvement in environmental management, they have also channeled situated knowledge into state-defined governance strategies and depoliticized the underlying causes of risks. Failure in municipal waste management is constructed as a lack of 'cultural order' rather than a consequence of structural inequality. As an official of the Secretaría de Recursos Naturales y Protección Ambiental (Ministry of Natural Resources and Environmental Protection, SERNAPAM) stated in a group discussion:

$<$ EXTRACT $>$ People need to change their mentality, not to think that all the problems are the fault of the government. With the production and recycle of waste, for example, what is needed is co-responsibilization and cultural appropriation of 
environment issues (Official of SERNAPAM, participant in a focus group discussion, 19 October 2011). </EXTRACT>

Against this backdrop of governmental techniques of self-responsibilization, Nygren organized discussions in which residents reflected on appropriate strategies to manage the risks and vulnerabilities they face. These knowledge encounters have opened up new understandings of the social geography of vulnerability as lived experiences of everyday uncertainties, and prompted residents to reconceptualize the meanings of responsibility under conditions of neoliberal governance in Villahermosa. In addition, Nygren organized workshops and training sessions with federal and state-level government authorities, city officials, private consultants and NGOs who promote participatory projects in marginal settlements. In these engagements, Nygren sought to foment a more nuanced understanding of the diverse conceptualizations of risk and responsibility in informal settlements such as Gaviotas Sur and encourage critical reflection of the prevailing techniques of governance.

These knowledge encounters have brought forth complex constructions of responsibility on the part of residents of Gaviotas Sur. Through their engagement in neoliberal discourses of risk prevention and waste management, the residents of Gaviotas Sur are playing an 'active role in their own governing' (Zeiderman, 2012: 1586), at times acquiescing to, at times reconfiguring and at times contesting the dominant discourses of responsibility and practices of governing. On several occasions, residents of Gaviotas Sur argued that they needed to improve their behavior in order to take better care of their environment, thus reproducing government officials' discourse that the waste problem stems from people's attitude of indifference. As Sandra said:

$<$ EXTRACT > There are many problems with drainage ... We're to blame, we litter, we throw bags and bottles to the streets and they get stuck the drains, which get horribly blocked. Why is it so hard to sweep in the morning? But people think: 'why should I sweep if others litter?' (Sandra, interview, 12 August 2011). </EXTRACT>

This acquiescence to governmental constructions of responsibility also emerged in discussions on risk prevention. After the 2007 flood, the Governor of Tabasco was heard on radio and television and quoted in local newspapers as stating that 'people need to calm down and stop spreading false rumors' (Rinne and Nygren, 2015). Such rumorología was considered characteristic especially of the 'poor, reluctant to adapt to living with water'. On several occasions, residents of Gaviotas Sur reproduced the Governor's message, suggesting that the flood reached such a magnitude because 'we didn't obey the authorities' instructions but spread false rumors'. As Adriana stated:

$<$ EXTRACT $>$ We lost much during the flood because we didn't pay attention. The Governor announced: 'Go away, because there will be a flood!' But people said: 'How can the Governor know if he is nothing like God? It was our fault for not leaving (Adriana, interview, 12 August 2011). </EXTRACT>

However, this does not indicate that residents passively adopted the prevalent rationalities of neoliberal governance. Many actively reconfigured the dominant meanings of responsibility through what Nielsen (2011: 331) calls 'inverse governmentality'. People attempted to 'regularize' their illicit land occupations by filling their plots with mud and sand to demonstrate to authorities that they are not living within the officially designated zone of flood risk. They renovated their simple wooden huts with cement and corrugated iron to show, as they said, that their houses were built 'with durable materials' and therefore they 
were 'up to standard'. They connected informal water tubes and electricity wires to official networks and mounted rustic street lamps in the shadowy alleyways in order to signify occupation. And they reinterpreted the meaning of street names established by municipal registers to justify their neighborhood as lived-in: 'The Street of Engineers' and 'The Street of Anthropologists' are now foster pride because, according to residents, 'it all sounds more official now'.

Through such inverse tactics, residents of Gaviotas Sur justified their right to cityspace on the basis of building their homes and daily lives in it, producing its landscape and suffering its floods and turbulent politics. They also questioned plans that called for governing informal settlements separately for more efficient risk prevention, pointing out that such policies of segregation provide affluent residents many kinds of privileges. In their view, such policies obfuscate how socially differentiated risks and vulnerabilities are linked to uneven access to everyday services, thus contextualizing the meanings of responsibility within an urban landscape constructed through uneven relations of power. As Luzmilda and Jaime argued:

$<$ EXTRACT $>$ The quality of services differs much depending on the zone and the status of the residents...In our zone, water and electricity come and go; they cut them to save... You have to wait for to wash the laundry. When the water comes with much pressure, it's dirty. When it comes with low pressure, it takes much time (Luzmilda, interview, 2 August 2011). </EXTRACT>

$<$ EXTRACT $>$ We're living at our own risk. There are no municipal scavengers in our neighborhood. And no pumping stations to remove the flood water from the streets (Jaime, interview, 18 October 2011).] </EXTRACT>

Many residents also actively contested the dominant meanings of responsibility reproduced by government officials. For example, women participating in group discussions claimed that the waste problem cannot be reduced to a cultural issue that places the responsibility on residents of informal settlements. Instead, the company providing the waste-collection services needs to recognize that many women in poor neighborhoods need to work outside the home in order to eke out a living with meager resources. Nora, who worked in an informal market in the downtown area, explained the problem of waste collection as follows:

$<$ EXTRACT $>$ We need to be alerted when the waste truck passes. We cannot leave the bags in advance because the dogs tear the bags and they don't pick up broken bags. On some days, the truck does not pass at all and we're waiting (Nora, interview, 2 August 2011). </EXTRACT>

Thus, residents contested the governmental technique of responsibilization through claims to alternative, situated knowledges and practices, which, in their view, should be understood as practical adaptations to flood risks that are structurally produced, rather than as illegal practices that induce or exacerbate flood risk. Since residents of Gaviotas Sur live in an unpredictable environment where conventional views of security and insecurity do not hold true, adjustment means developing day to-day strategies to 'cope with emergencies as they occur' (Lahiri-Dutt and Samanta, 2013: 139). Rather than accepting the premise of responsibility reproduced in governmental risk-management programs, residents of Gaviotas Sur actively contested the neoliberal agendas of self-responsibilization by appealing to situated knowledges of adaptation and survival. As Julio explained: 
$<$ EXTRACT > They have spread much propaganda that we need to adapt to floods. But the 2007 flood was caused by the bad operation of dams. The electricity companies filled the reservoirs with water to produce much electricity and then released too much water ... They also try to divert the excessive water to other areas, but this is impossible. The river always searches its channel. We know this because we are living along the riverbank (Julio, interview, 18 August 2011). </EXTRACT>

Drawing on these tropes of struggle, survival and everyday knowledge, residents of Gaviotas Sur took advantage of the knowledge encounters facilitated by engaged ethnography to shift the construction of responsibility from the residents to the government. Through critical engagement in these knowledge encounters, they began to argue that the community should organize to demand that government improves public welfare and strengthens flood protection in places such as Gaviotas Sur. In this counterhegemonic construction of responsibility, government is seen as responsible for providing basic services of water, waste management and other aspects of daily life for all citizens, regardless of their social status. While it is important not to idealize informal agency (Roy, 2011), the location of these alternative constructions of responsibility within government rather than the individual differs fundamentally from the neoliberal agenda, which emphasizes the provision of infrastructure services through private incentives and civic self-help. They also depart from the conventional conceptions of differentiated citizenship that assign different rights for different categories of residents (Holston, 2011; Centner, 2012).

As in the case of Sletto's work in Santo Domingo, Nygren's ethnographically engaged research process in Villahermosa has facilitated alternative enactments of responsibility and new forms of knowledge production among diverse actors. However, these engagements have not been without certain limitations. In meetings with institutional actors, officials often expected Nygren to take on the role of facilitator to help them 'educate' residents in order to produce 'accountable citizens' and to provide authorities with strategic advice in order to quell attempts at political mobilization. At the same time, residents expected her to act as their advocate in political struggles for enhanced services and improved representation in public policy, forcing her to continuously and uneasily navigate between contested truth claims and forms of knowledge production.

\section{$<\mathrm{H} 1>$ Conclusions $</ \mathrm{H} 1>$}

In this article, we have presented the struggles of residents in the informal settlements of Los Platanitos in Santo Domingo Norte and Gaviotas Sur in Villahermosa, as they grapple with serious environmental and social implications of inadequate solid waste management and mitigation of environmental hazards, in particular the omnipresent risk of severe flooding. We have shown that despite their different historical, social and geographical contexts, both communities are subject to neoliberal forms of environmental governance premised on hegemonic discourses of civic participation. Furthermore, we have demonstrated that the rationality of participatory governance both in Santo Domingo and Villahermosa is reproduced through political practices, in particular through governmental techniques of responsibilization whereby residents in informal settlements are produced as neoliberal subjects who are responsible for participating in their own governance.

However, the research in Los Platanitos and Gaviotas Sur also suggests that governance through techniques of responsibilization is fragmented, spatially contingent and incomplete. As we have demonstrated in both cases, residents not merely acquiesce to the meanings of responsibility that emerge from neoliberal rationales of participatory governance, but also reconfigure and contest these hegemonic constructions of responsibility. Their reconceptualizations of hegemonic constructions of responsibility are similarly 
contingent and situated as residents engage in an ongoing, critical and reflective process of subject formation.

In our article, we have examined our own roles as engaged ethnographers in fomenting, complicating and perhaps contradicting such alternative articulations of responsibility. In the case of Los Platanitos, Sletto facilitated connections between residents and community organizations from other neighborhoods, which led to new forms of thinking and speaking about responsibility but which also, inadvertently, introduced neoliberal rationalities of commodification of waste management. In the case of Gaviotas Sur, Nygren was invited by governmental officials into participatory spaces, such as workshops and focusgroup discussions, where she was expected to serve as facilitator and representative of sorts for government interests, but where she also facilitated critical reflections among residents of their rights and responsibilities in terms of flood control and solid-waste management.

In order to critically consider the implications of our interventions in these contested landscapes of neoliberal rationality, we have conceptualized our ethnographic engagement as structured through 'knowledge encounters' that have facilitated reflective co-production of alternative knowledges. While neoliberal structures of inclusion provide previously excluded actors with opportunities to participate in environmental management, they also construct a new, neoliberal subject attuned to the hegemonic knowledge formations and rationalities of participatory planning and development. That is to say, we understand the governmental techniques of responsibilization as dominant projects of knowledge production, whereby residents are subject to participatory rationalities of governance and, in so doing, internalize and 'enact' their production of self as neoliberal subjects ultimately responsible for both causing and resolving the challenges they face.

However, we have proposed that such enactments of self are also constitutive of alternative forms of knowledge production. This raises the question of the opportunities for ethnographic engagement to generate stages for enactments of self that are transformative and that have the potential to foment emancipatory subjectivities. We have suggested that the fractured and incomplete projects of neoliberal governance provide spaces for the sort of critical knowledge encounters we have described in our article, providing opportune stages for residents of informal settlements to negotiate the neoliberal techniques of governance through ambiguous forms of acquiescence, reconfiguration and contestation.

At the same time, it is important to consider whether these new forms of knowledge production among local residents and their collaborators are deliberative and effective enough to destabilize institutionalized relations of power and promote more just forms of governance. Even though we, as engaged scholars, have tried to continuously challenge hegemonic forms of neoliberal governance, our work in Santo Domingo Norte and Villahermosa is inevitably and problematically situated within neoliberal structures of engagement. However, the fact that such efforts may fail to significantly change material conditions does not negate the critical value of such encounters, where the main focus is on knowledge production as a process rather than a product and on learning as engagement rather than on the lessons learnt. As Biehl (2013: 583-84) suggests, the goal of ethnographic engagement is to develop spaces for co-production of knowledge that have a potential to generate new forms of reasoning and new ways of acting.

To facilitate such generative and alternative forms of knowledge production requires a reflective attitude towards research and a radical rethinking of the traditional dichotomy between the researcher and the researched. This rethinking begins by critically questioning how far we, as engaged scholars, can speak of risk and responsibility as universal concepts, and what gives us ownership of these terms in particular contexts. Our ethnographic engagement has convinced us that the problem is not simply that the 'subaltern cannot speak' (Spivak, 1988), but that we, as engaged scholars, often hear them in highly selective ways, 
based on our own assumptions. If we are unable to reflect rigorously on our own positionality and the normative structures of participation that shape our work under neoliberal governance, we may fail to understand how different forms of knowing are co-produced in hybrid and contingent processes among actors who perform different and often contradictory roles in the knowledge encounters facilitated by ethnographic engagement.

Herein lies perhaps the opportunity for the production of emancipatory subjectivities under neoliberal governance: while participatory structures furnish a means of epistemological disciplining, these fragmented arenas of networked governance also offer spaces for new forms of knowledge production by and for previously excluded actors. Despite the hegemonic constructions of responsibility and fields of participation that characterize neoliberal governance, these regimes also provide unexpected opportunities for oppositional enactments of selves. It is here, in the spaces of engagement made possible by the participatory rationality of neoliberal governance, where engaged ethnography can play an important role in facilitating critical knowledge encounters and, in so doing, contribute to alternative thinking and creative action in order to manage the pressing environmental challenges facing communities such as Los Platanitos and Gaviotas Sur.

\section{<AUTHOR(S) TAG LINE (END-OF-TEXT)/AFFILIATIONS>}

Bjorn Sletto, The University of Texas at Austin, School of Architecture, 310 Inner Campus Drive Stop B7500, Austin, Texas 78712-1009, USA, bjorn@utexas.edu and Anja Nygren, PL 18, Unionkatu35, 00014-University of Helsinki, Finland anja.nygren@ helsinki.fi

\section{$<$ RH1 $>$ References $</$ RH1 $>$}

Agrawal, A. (1995) Dismantling the divide between indigenous and scientific knowledge. Development and Change 26.3, 413-39.

Alexander, M.J. and C.T. Mohanty (2010) Cartographies of knowledge and power: transnational feminism as radical praxis. In A.L. Swarr and R. Nagar (eds.), Critical transnational feminist praxis, State University of New York Press, Albany, NY.

Asher, N. (2005) At the interstices: engaging postcolonial and feminist perspectives for a multicultural education pedagogy in the South. College Record 107.5, 89-106.

Ayuntamiento del Distrito Nacional (2011) Reglamento del servicio de manejo de los residuos sólidos municipales no peligrosos en el territorio del Ayuntamiento del Distrito Nacional. Ayuntamiento del Distrito Nacional, Santo Domingo. [Management regulations for non-hazardous municipal solid waste services in the municipality of Distrito Nacional. Municipality Distrito Nacional, Santo Domingo.] URL http://www.google.com/url?sa=t\&rct=j\&q=\&esrc=s\&source=web\&cd=10\&ved=0CG kQFjAJ\&url=http\%3A\%2F\%2Fwww.adn.gob.do\%2Fjoomlatools-files\%2Fdocmanfiles\%2FReglamento\%2520Municipal\%2520de\%2520Aseo.pdf\&ei=D4zuU534KdHi oASo7YCwBg\&usg=AFQjCNEH3RkEUyAnVUf_F8Nc1WzYp1AUg\&bvm=bv.73231344,d.cGU\&cad=rja (accessed 14 August 2014).

Baiocchi, G. and E. Ganuza (2014) Participatory budgeting as if emancipation mattered. Politics \& Society 42.1, 29-50.

Bartlett, L. (2005) Dialogue, knowledge, and teacher-student relations: Freirean pedagogy in theory and practice. Comparative Education Review 49.3, 344-64.

Bayat, A. and K. Biekart (2009) Cities of extremes. Development and Change 40.5, 815-25.

Biehl, J. (2013) Ethnography in the way of theory. Cultural Anthropology 28.4, 573-97.

Blomley, N. (2008) The spaces of critical geography. Progress in Human Geography 32.2, 285-93.

Bogaert, K. (2011) The problem of slums: shifting methods of neoliberal urban government in Morocco. Development and Change 42.3, 709-31. 
Bosman, M. and M. Amen (2006) Recasting neo-liberalism in the Americas: a critique of the preliminary needs assessment of the Millennium Development Goals in the Dominican Republic. Globalizations 3.2, 227-36.

Bossin, M. (2009) Women, employment, and empowerment in the Dominican Republic: the case of Los Platanitos, Santo Domingo. Master's thesis, Austin School of Architecture, University of Texas, Austin, TX.

Brown, M. and L. Knopp (2008) Queering the map: the productive tensions of colliding epistemologies. Annals of the Association of American Geographers 98.1, 40-58.

Caldeira, T. (2008) From modernism to neoliberalism in São Paulo: reconfiguring the city and its citizens. In A. Huyssen (ed.), Other cities, other worlds: urban imaginaries in a globalizing age, Duke University Press, Durham, NC.

Centner, R. (2012) Microcitizenships: fractious forms of urban belonging after Argentine neoliberalism. International Journal of Urban and Regional Research 36.2, 336-62.

Cerwonka, A. and L.H. Malkki (2007) Improvising theory: process and temporality in ethnographic fieldwork. University of Chicago Press, Chicago. IL.

Chantada, A. (2014) The state, the city, and participation in civil society in the Dominican Republic. Planning Theory \& Practice 15.4, 586-588.

Clarke, J. (2005) New Labour's citizens: activated, empowered, responsibilized, abandoned? Critical Social Policy 25.4, 447-63.

Clarke, K.M. (2010) Toward a critically engaged ethnographic practice. Current Anthropology 51.S2, S301-12.

Coaffee, J. (2013) Rescaling and responsibilising the politics of urban resilience: from national security to local place-making. Politics 33.4, 240-52.

Comack, E. and E. Bowness (2010) Dealing the race card: public discourse on the policing of Winnipeg's inner-city communities. Canadian Journal of Urban Research 19.1, 34 50.

CONAGUA (2011) Cultura del agua. [Culture of water [WWW document]. URL http://www.conagua.gob.mx/Contenido.aspx?n1=6\&n2=200\&n3=200

(accessed 23 July 2011). Dawson, A. (2004). Squatters, space, and belonging in the underdeveloped city. Social Text 22.4, 17-34.

Díaz, O. (2011) Los Platanitos revisited: establishing an environmental educational program. Master's thesis, Community and Regional Planning, The University of Texas, Austin, TX.

Elden, S. (2007) Rethinking governmentality. Political Geography 26.1, 29-33.

Elwood, S.A. (2006) Negotiating knowledge production: the everyday inclusions, exclusions, and contradictions of participatory GIS research. The Professional Geographer 58.2, 197-208.

Elwood, S.A. (2009) Integrating participatory action research and GIS education: negotiating methodologies, politics and technologies. Journal of Geography in Higher Education $33.1,51-65$.

Flint, J. (2002) Social housing agencies and the governance of anti-social behavior. Housing Studies 17.4, 619-38.

Foucault, M. (2003) The birth of biopolitics. In P. Rabinow and N. Rose (eds.), The essential Foucault: selections from essential works of Foucault 1954-1984, The New Press, London.

Foucault, M. (2007) Security, territory, population. Palgrave, Basingstoke.

Fraser, N. (2009) Scales of justice: reimagining political space in a globalizing world. Columbia University Press, New York, NY.

Gabay, C. (2011) Consenting to 'heaven': the Millennium Development Goals, neo-liberal governance and global civil society in Malawi. Globalizations 8.4, 487-501. 
Gandy, M. (2006) Planning, anti-planning and the infrastructural crisis facing metropolitan Lagos. Urban Studies 43.2, 71-96.

Gandy, M. (2008) Landscapes of disaster: water, modernity, and urban fragmentation in Mumbai. Environment and Planning A 40.1, 108-30.

GET (Gobierno del Estado de Tabasco) (2010) Evaluación y actualización: plan estatal de desarrollo 2007-2012 [Evaluation and Actualization: State Development Plan 20072012.] Gobierno del Estado de Tabasco, Tabasco.

Ghose, R. (2007) Politics of scale and networks of association in public participation GIS. Environment and Planning A 39.8, 1961-80.

Goldfrank, B. and A. Schrank (2009) Municipal neoliberalism and municipal socialism: urban political economy in Latin America. International Journal of Urban and Regional Research 33.2, 443-62.

Guarneros-Meza, V. (2009) Mexican urban governance: how old and new institutions coexist and interact. International Journal of Urban and Regional Research 33.2, 463-82.

Gunder, M. and J. Hillier (2007) Planning as urban therapeutic. Environment and Planning A 39.4, 467-86.

Haraway, D. (1991) Simians, cyborgs, and women: the reinvention of nature. Free Association Books, London.

Holston, J. (2011) Contesting privilege with right: the transformation of differentiated citizenship in Brazil. Citizenship Studies 15.3-4, 335-52.

Lacey, A. and S. Ilcan (2006) Voluntary labor, responsible citizenship, and international NGOs. International Journal of Comparative Sociology 47.1, 34-53.

Lahiri-Dutt, K. and G. Samanta (2013) Dancing with the river: people and life on the chars of South Asia. Yale University Press, New Haven, CT.

Lee, C.W. (2014) Walking the talk: the performance of authenticity in public engagement work. The Sociological Quarterly 55.3, 493-513.

Lee, C.W. (2015) Do-it-yourself democracy: the rise of the public engagement industry. Oxford University Press, Oxford.

Lemke, T. (2001) The birth of bio-politics: Michel Foucault's lecture at the College de France on neo-liberal governmentality. Economy and Society 30.2, 190-207.

Li, T.M. (2007) The will to improve: governmentality, development and the practice of politics. Duke University Press, Durham, NC.

Mckee, K. (2009) Post-Foucauldian governmentality: what does it offer critical social policy analysis? Critical Social Policy 29.3, 465-86.

Miraftab, F. (2009) Insurgent planning: situating radical planning in the global South. Planning Theory 8.1, 32-50.

Mitchell, C. (2008) La República Dominicana 2007: buscando la institucionalidad. [The Dominican Republic 2007: searching for institutionalism]. Revista de Ciencia Política $28.1,171-87$.

Mohanty, C.T. (2003) Feminism without borders: decolonizing theory, practicing solidarity. Duke University Press, Durham, NC.

Mullins, P.R. (2011) Practicing anthropology and the politics of engagement: 2010 year in review. American Anthropologist 113.2, 235-45.

Nielsen, M. (2011) Inverse governmentality: the paradoxical production of peri-urban planning in Maputo, Mozambique. Critique of Anthropology 31.4, 329-58.

Nygren, A. (1999) Local knowledge in the environment-development discourse: from dichotomies to situated knowledges. Critique of Anthropology 19.3, 267-88.

Osterweil, M. (2013) Rethinking public anthropology through epistemic politics and theoretical practice. Cultural Anthropology 8.4, 598-620.

Peake, L. and K. de Souza (2010) Feminist academic and activist praxis in service of the 
transnational. In A.L. Swarr and R. Nagar (eds.), Critical transnational feminist praxis. State University of New York Press, Albany, NY.

PEOT (2008) Programa estatal de ordenamiento territorial y desarrollo urbano del Estado de Tabasco 2007-2012. [State Program of Territorial Ordering and Urban Development of the State of Tabasco 2007-2012.] Gobierno del Estado de Tabasco, Tabasco.

Pusch, C. (2010) An analysis of informal housing: the case of Los Platanitos, Santo Domingo Norte, Dominican Republic. Master's thesis, Community and Regional Planning, University of Texas, Austin, TX.

Raco, M. (2007) Securing sustainable communities: citizenship, safety and sustainability in the new urban planning. European Urban and Regional Studies 14.4, 305-320.

Rinne, P. and A. Nygren (2015) From resistance to resilience: media discourses on urban flood governance in Mexico. Journal of Environmental Policy and Planning 17, 1-22.

Rose, N. (2000) Government and control. British Journal of Criminology 40.2, 321-39.

Rose, N., P. O'Malley and M. Valverde (2006) Governmentality. Annual Review of Law and Social Science 2, 83-103.

Roy, A. (2005) Urban informality: toward an epistemology of planning. Journal of the American Planning Association 71.2, 147-58.

Roy, A. (2011) Slumdog cities: rethinking subaltern urbanism. International Journal of Urban and Regional Research 35.2, 223-38.

Secretaría de Estado de Educación (2003) Plan estratégico de desarrollo de la educación Dominicana 2003-2012 [National development strategy for education in the Dominican Republic 2003-2012]. Secretaría de Estado de Educación, República Dominicana, Santo Domingo.

Senado de la República Dominicana (2012) Ley orgánica de la estrategia nacional de desarrollo de la República Dominicana 2010-2030. [Organic Law of National Development Strategy for the Dominican Republic 2010-2030] [WWW document]. URL http://www.google.com/url?sa=t\&rct=j\&q=\&esrc=s\&source=web\&cd=1\&cad=rja\&u act $=8 \& v e d=0$ CB0QFjAA\&url=http $\% 3 \mathrm{~A} \% 2 \mathrm{~F} \% 2 \mathrm{Fwww} \cdot$ senado.gob.do $\% 2 \mathrm{Fsenado} \% 2$ Fportals\%2F0\%2Fdocumentos\%2FProyectos\%2520de\%2520Leyes\%2F453B.pdf\&ei =Hn3uU670NciJogSJ4IKABg\&usg=AFQjCNFp6WpaMZ1 xOyQ-m919gVshTDdAg\&bvm=bv.73231344,d.cGU (accessed 15 August 2014).

Shamir, R. (2008) The age of responsibilization: on market-embedded morality. Economy and Society 37.1, 1-19.

Shapiro, M.J. (2013) Studies in trans-disciplinary method: after the aesthetic turn. Routledge, Abingdon.

Shore, C. and S. Wright (2011) Conceptualising policy: technologies of governance and the politics of visibility. In C. Shore, S. Wright and D. Però (eds.), Policy worlds: anthropology and the analysis of contemporary power, Berghahn Books, Oxford.

Simone, A. (2008) Emergency democracy and the 'governing composite'. Social Text 26.2, $13-33$.

Spivak, G.C. (1988) Can the subaltern speak? In C. Nelson and L. Grossberg (eds.), Marxism and the interpretation of culture, Macmillan, Basingstoke.

Strange, S. (2010) The integration of emergency economies in developing countries: the case of Los Platanitos, Santo Domingo Norte, Dominican Republic. Master's thesis, Austin School of Architecture, University of Texas, Austin, TX.

Swyngedouw, E. (2005) Governance innovation and the citizen: the Janus face of governance-beyond-the-state. Urban Studies 42.11, 1191-2006.

Trnka, S. and C Trundle (2014) Competing responsibilities: moving beyond neoliberal 
responsibilisation. Anthropological Forum: Journal of Social Anthropology and Comparative Sociology 24.2, 136-53.

Walsh, A. (2005) The obvious aspects of ecological underprivilege in Ankarana, northern Madagascar. American Anthropologist 107.4, 654-65.

Zeiderman, A. (2012) On shaky ground: the making of risk in Bogotá. Environment and Planning A 44.7, 1570-88.

\section{<UNNUMBERED FOOTNOTE TO GO AT FOOT OF FIRST PAGE>}

Research for this article was funded by the US Environmental Protection Agency P3

Program, The University of Texas, the Academy of Finland and the University of Helsinki. We are grateful to the residents of Santo Domingo and Villahermosa and to the many governmental institutions, private companies and non-governmental organizations in the Dominican Republic and Mexico that cooperated with our field research. In particular, we offer thanks to Gabriel Báez, Santo Domingo; Juan Torres, Ayuntamiento Distrito Nacional, Dominican Republic; and the women and men of Mujeres Unidas and FUMPLA. We also wish to thank the three anonymous IJURR reviewers, who provided constructive and highly valuable comments on our manuscript.

\section{$<$ NUMBERED FOOTNOTES $>$}

$<$ F1 $>$ The distinction between 'ordinary ethnography' and 'engaged ethnography' is neither clear nor categorical. In fact, many ethnographers become involved in diverse engagements with their study subjects, including collaborative deconstruction of hegemonic thinking, advocacy work, social activism, action research and/or reflective public engagement. In this respect, see, for example, Clarke (2010), Biehl (2013), Osterweil (2013) and Lee (2015). $<\mathrm{F} 2>$ Pseudonyms have been used to ensure interviewees' anonymity.

$<$ F3 $>$ In vermicomposting, also known as vermiculture, earthworms are used to speed up the decomposition process. 